\title{
Multi-century tree-ring based reconstruction of the Neuquén River streamflow, northern Patagonia, Argentina
}

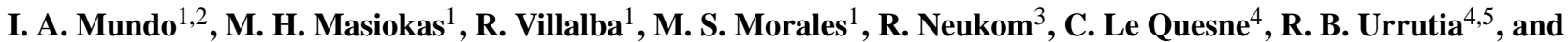 \\ A. Lara $^{4}$ \\ ${ }^{1}$ Departamento de Dendrocronología e Historia Ambiental, IANIGLA, CCT CONICET Mendoza, Mendoza, Argentina \\ ${ }^{2}$ LISEA, Facultad de Ciencias Agrarias y Forestales, Universidad Nacional de La Plata, La Plata, Argentina \\ ${ }^{3}$ School of Earth Sciences, University of Melbourne, Melbourne, Australia \\ ${ }^{4}$ Laboratorio de Dendrocronología, Instituto de Silvicultura, Facultad de Ciencias Forestales y Recursos Naturales, \\ Universidad Austral de Chile, Valdivia, Chile \\ ${ }^{5}$ Environmental Change Institute, School of Geography and the Environment, University of Oxford, Oxford, UK
}

Correspondence to: I. A. Mundo (iamundo@mendoza-conicet.gob.ar)

Received: 6 October 2011 - Published in Clim. Past Discuss.: 21 October 2011

Revised: 12 March 2012 - Accepted: 29 March 2012 - Published: 20 April 2012

\begin{abstract}
In most cases, gauged river flow records in southern South America extend for only a few decades, hampering the detection of long-term, decadal to centennialscale cycles and trends. Long streamflow series can be reconstructed from tree-ring records, offering the opportunity of extending the limited hydrological instrumental data to several centuries. In northern Patagonia, Argentina, the Neuquén River has great importance for local and national socio-economic activities such as hydroelectric power generation, agriculture and tourism. In this study, new and updated tree-ring chronologies from Araucaria araucana and Austrocedrus chilensis are used to reconstruct the October-June mean streamflow for the Neuquén River and place the period of gauged flows (1903-2009), in a long-term, multi-century context. The reconstruction covers the period 1346-2000 AD and was developed from a network of 43 tree-ring chronologies, grouped in composite series, using a nested principal component regression approach. Analyses of the frequency, intensity, and duration of droughts and pluvial events indicate that the 20th century contains some of the driest and wettest annual to decadal-scale events in the last $654 \mathrm{yr}$, but longer and more severe events were recorded in previous centuries. Blackman-Tukey and singular spectral analyses identified quasiperiodic oscillations from 3.5 to $17.5 \mathrm{yr}$. A dominant 6.8 -yr cycle explains ca. $23.6 \%$ of the total variance in the Neuquén River streamflow reconstruction. Correlation analyses showed that discharges of the Neuquén River are
\end{abstract}

related to variations in the Southern Annular Mode (SAM), a measure of air mass exchanges between middle and high latitudes in the Southern Hemisphere. This association is consistent with previous studies that indicate a strong correlation between rainfall in northern Patagonia and SAM variations.

\section{Introduction}

The management of water resources requires comprehensive knowledge of the natural variability in streamflows over multiple time scales (Woodhouse and Lukas, 2006). Gauged river flow records in southern South America are, in most cases, a few decades in length, with few records longer than $100 \mathrm{yr}$. Although such relatively short records are conventionally used as a basis for planning and engineering design, they are too short to properly determine the true flow frequency or the return period, severity, and duration of dry and wet events. Long-term trends and decadal to centennial-scale cycles are also difficult to estimate with short time series, but they can be detected using long streamflow series reconstructed from tree-ring records (Stockton, 1975; Cook and Jacoby, 1983; Case and MacDonald, 2003; Woodhouse et al., 2006; Lara et al., 2008). By further examining the frequency (events per time period), intensity (departures from the median), and duration of events (consecutive years below or above the long-term median) in the proxy records, water 

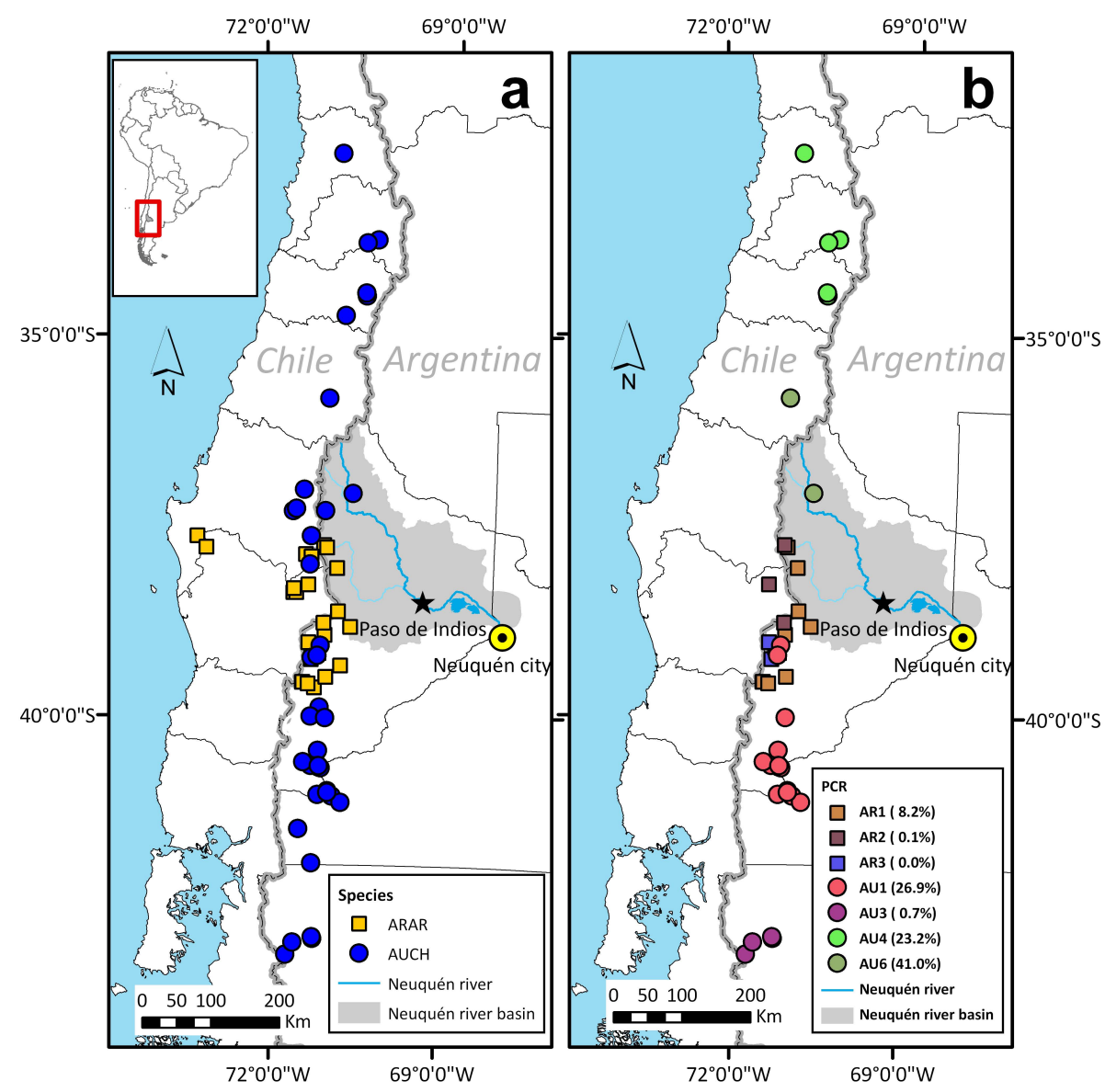

Fig. 1. Maps showing the Neuquén River basin (shaded area), the location of the Paso de Indios gauging station (black star), and the location of the 66 tree-ring sites initially considered as predictors (a), and the final subset of chronologies in the reconstruction (b). Sites are differentiated by species (a) and by beta weights of the composite chronologies over their common period 1676-2000 AD (b). The beta weights represent the explanatory power of the composite chronologies (see text for details). ARAR: Araucaria araucana; AUCH: Austrocedrus chilensis. For composite chronologies codes, see Table 1 in the Supplement.

resource managers may integrate reconstructed streamflow into infrastructure planning and management decisions.

The Neuquén River is one of the main rivers in the north Patagonian Andes of Argentina and drains an extensive area between $36^{\circ} \mathrm{S}$ and $39^{\circ} \mathrm{S}$ (Fig. 1). This river is used to generate hydroelectricity at the Cerros Colorados Hydropower Complex (the Planicie Banderita plant has 479 MW of installed capacity). Two large reservoirs (Los Barreales and Mari Menuco) have made extensive irrigated agriculture possible in the region. The Neuquén River has a continuous gauging station record beginning in April 1903, which is free of human interventions such as the above-mentioned dams. This record represents one of the longest and best quality series in southern South America.

A preliminary dendrochronological study extended the flow series of the Neuquén and Limay Rivers back to 1601 AD (Holmes et al., 1979). This work used seven treering chronologies (five from Araucaria araucana and two from Austrocedrus chilensis) available at that time. Recently, the $A$. araucana tree-ring network has been updated and expanded, encompassing 17 well-replicated chronologies that cover the period 1140-2006 AD (Mundo et al., 2012). In addition, the $A$. chilensis tree-ring network has increased to a total of 39 chronologies, including the 1800-yr long tree-ring chronology from Huinganco in the northwestern corner of the Neuquén Province (Villalba and Veblen, 1997; Morales and Boninsegna, 2000; Le Quesne et al., 2006, 2009; Christie et al., 2010). This greatly improved tree-ring network, in combination with new techniques for chronology development and climate reconstruction, provides renewed interest to improve and extend back in time the existing streamflow reconstruction for the Neuquén River with higher statistical confidence.

In this study we develop a multi-century tree-ring based reconstruction for the Neuquén River streamflow using a nested principal component regression approach. We analyze the temporal variations in water discharge and put recent streamflow variations and trends in the context of the past 
six centuries. To facilitate the use of the reconstruction for water resource management, we also analyze the frequency, intensity, and duration of drought and pluvial events in the reconstruction and compare the reconstructed values to those observed during the instrumental period. Finally, in order to identify the major climatic forcings influencing river discharge, we compare the Neuquén River reconstruction with hemispheric or global atmospheric circulation indexes.

\section{Data and methods}

\subsection{Streamflow data}

The Neuquén River basin covers $49958 \mathrm{~km}^{2}$, including mainly the northern part of the Neuquén Province and a small northwestern portion of the Río Negro Province in northwestern Patagonia, Argentina (Fig. 1). As mentioned above, this river is regulated in the lower part of the basin by the Cerros Colorados Complex, which consists of four dams (Portezuelo Grande, Loma de la Lata, Planicie Banderita and El Chañar). Their primary purposes are to control surges, regulate flows and ensure water supply for human consumption, irrigation, and hydroelectric generation.

The hydrological year for the Neuquén streamflow goes from April to March (Fig. 2). The hydrograph is characterized by a bimodal regime: the first peak occurs in winter associated with cold season precipitation in the upper basin, and the second peak in late spring largely due to snow melt. The Subsecretaría de Recursos Hídricos de la Nación (SSRH, the National Agency of Water Resources of Argentina) has eight gauges throughout the Neuquén basin. The Paso de Indios record ( $38^{\circ} 31^{\prime} 55^{\prime \prime} \mathrm{S}$; $69^{\circ} 24^{\prime} 49^{\prime \prime} \mathrm{W} ; 498 \mathrm{~m}$ a.s.l.; Fig. 1) is one of the longest records available in southern South America (1903-2011). The average flow of the Neuquén River at Paso de Indios is $312 \mathrm{~m}^{3} \mathrm{~s}^{-1}$, but maximum flows of up to $10350 \mathrm{~m}^{3} \mathrm{~s}^{-1}$ have been recorded at the Portezuelo Grande dam. Correlations between all possible combinations of monthly streamflows and tree-ring data were evaluated in order to determine the most appropriate season to develop the streamflow reconstruction.

\subsection{Tree-ring network}

The tree species selected to develop the Neuquén River streamflow reconstruction were the precipitation-sensitive, evergreen conifers, Araucaria araucana and Austrocedrus chilensis. A. araucana extends from ca. $37^{\circ} 20^{\prime}$ to $40^{\circ} 20^{\prime} \mathrm{S}$ in the Andes of southwestern Argentina and south-central Chile (Veblen, 1982). This species is found in elevations as low as $600 \mathrm{~m}$ (especially on the Argentinean side of the Andes) to ca. $1800 \mathrm{~m}$ and $1500 \mathrm{~m}$ in the northern and southern timberlines along its distribution range, respectively. Annual precipitation in this region ranges from ca. $1200 \mathrm{~mm}$ on the Argentinean side of the Andes to well over $4000 \mathrm{~mm}$ on the west-facing slopes at ca. $39^{\circ} \mathrm{S}$ (Almeyda and Sáez,

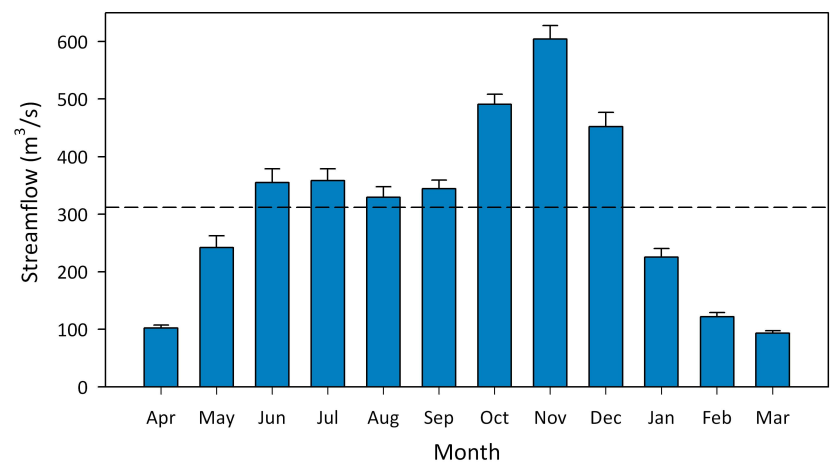

Fig. 2. Mean monthly variations (with standard error bars) of the Neuquén River streamflow at the Punta de Indios gauging station (period 1903-2009) over the complete hydrological year (AprilMarch). Dashed line represents the historical mean $\left(312 \mathrm{~m}^{3} \mathrm{~s}^{-1}\right)$ for the 1903-2009 period.

1958). The climate in these areas has a Mediterranean regime with a peak of precipitation in winter and dry summers (Donoso-Zegers, 1993). The intensity and duration of summer droughts increase markedly northwards and are reflected in the species-poor and sparse understory vegetation in the northerly Araucaria stands. Araucarias of ca. $900 \mathrm{yr}$ of age have been recorded from marginal forest patches on rocky outcrops surrounded by the xeric steppe and in the northern slope of Lanín Volcano in Argentina (LaMarche et al., 1979; Mundo et al., 2012).

Austrocedrus grows mainly on the steep topography of the Andean Cordillera between $32^{\circ} 39^{\prime} \mathrm{S}$ and $38^{\circ} \mathrm{S}$ on the western slopes and between $37^{\circ} 07^{\prime}$ and $43^{\circ} 44^{\prime} \mathrm{S}$ on the eastern slopes of the Andes. The growth of Austrocedrus is particularly sensitive to precipitation. Individuals can live more than $1200 \mathrm{yr}$ (Villalba and Veblen, 1997; Le Quesne et al., 2006). Wood samples from Austrocedrus at El Asiento (Chile, $32^{\circ} 40^{\prime} \mathrm{S} ; 70^{\circ} 49^{\prime} \mathrm{W}$ ) and Huinganco (Argentina, $36^{\circ} 30^{\prime} \mathrm{S} ; 70^{\circ} 36^{\prime} \mathrm{W}$ ) stands have provided exceptionally long chronologies covering the past 1200 to $1800 \mathrm{yr}$, respectively (Morales and Boninsegna, 2000; Le Quesne et al., 2006).

The tree-ring data considered in this study (66 individual chronologies) were obtained from unpublished collections and published chronologies freely available on the International Tree-Ring Data Bank (http://www.ncdc.noaa.gov/ paleo/treering.html) (Fig. 1, Table 1 and Table 1 in the Supplement). Although many chronologies are located outside of the Neuquén River basin, they were all initially included as potential predictors of streamflows to capture the regionalscale hydroclimatic variability related to the Neuquén River discharge (Cook et al., 1999; Woodhouse and Lukas, 2006).

The development of regional composite tree-ring chronologies involved two steps. First, series shorter than $100 \mathrm{yr}$ were removed and the remaining tree-ring width series were standardized using a cubic spline function 
Table 1. Descriptive statistics for composite chronologies.

\begin{tabular}{|c|c|c|c|c|c|c|c|c|c|c|}
\hline \multirow{2}{*}{$\begin{array}{l}\text { Species/comp. } \\
\text { code }\end{array}$} & \multirow{2}{*}{$\begin{array}{r}\text { Complete } \\
\text { period }\end{array}$} & \multirow{2}{*}{$\begin{array}{c}\text { Period } \\
\text { EPS }^{1}> \\
0.85\end{array}$} & \multirow{2}{*}{$\begin{array}{l}\text { n. of } \\
\text { sites }\end{array}$} & \multirow{2}{*}{$\begin{array}{l}\text { n. of } \\
\text { series }\end{array}$} & \multicolumn{2}{|c|}{ Raw data } & \multicolumn{2}{|c|}{ Standard chronology } & \multirow{2}{*}{$\begin{array}{c}\text { AR } \\
\text { Model }\end{array}$} & \multirow{2}{*}{$\begin{array}{c}\text { Correl. } \\
\text { coeff. with } \\
\text { O-J } \\
\text { Neuquén } \\
\text { River } \\
\text { streamflow }\end{array}$} \\
\hline & & & & & $\begin{array}{l}\mathrm{RW}^{2} \\
(\mathrm{~mm})\end{array}$ & $\mathrm{MS}^{3}$ & $\begin{array}{c}\text { Mean } \\
\text { RBAR }^{4}\end{array}$ & Autocorrel. $^{5}$ & & \\
\hline \multicolumn{11}{|c|}{ Araucaria araucana } \\
\hline AR1 & 1162-2006 & $1345-2006$ & 11 & 487 & 0.854 & 0.204 & 0.150 & 0.671 & $\mathrm{AR}(5)$ & 0.440 \\
\hline AR2 & 1264-2006 & $1645-2006$ & 3 & 70 & 0.859 & 0.203 & 0.160 & 0.759 & $\mathrm{AR}(5)$ & 0.204 \\
\hline AR3 & 1450-2006 & 1710-2006 & 2 & 81 & 1.016 & 0.211 & 0.168 & 0.649 & $\operatorname{AR}(4)$ & 0.299 \\
\hline \multicolumn{11}{|c|}{ Austrocedrus chilensis } \\
\hline AU1 & $1461-2003$ & $1486-2003$ & 16 & 541 & 0.669 & 0.266 & 0.199 & 0.640 & $\operatorname{AR}(7)$ & 0.283 \\
\hline AU2 & 1144-2005 & $1200-2005$ & 4 & 406 & 0.642 & 0.263 & 0.221 & 0.630 & $\mathrm{AR}(3)$ & 0.104 \\
\hline AU3 & 1540-2002 & $1675-2002$ & 4 & 156 & 0.895 & 0.290 & 0.251 & 0.595 & $\mathrm{AR}(3)$ & 0.240 \\
\hline AU4 & 955-2002 & $1160-2002$ & 5 & 369 & 0.633 & 0.257 & 0.187 & 0.626 & $\operatorname{AR}(6)$ & 0.524 \\
\hline AU5 & $1613-1975$ & $1670-1975$ & 2 & 64 & 0.654 & 0.215 & 0.283 & 0.706 & $\mathrm{AR}(3)$ & 0.075 \\
\hline AU6 & 190-2005 & $1125-2005$ & 2 & 271 & 0.834 & 0.264 & 0.168 & 0.668 & $\mathrm{AR}(3)$ & 0.258 \\
\hline
\end{tabular}

${ }^{1} \mathrm{EPS},=$ expected population signal; ${ }^{2} \mathrm{RW}$, Mean ring width; ${ }^{3} \mathrm{MS},=$ mean sensitivity; ${ }^{4}$ Mean RBAR $=$ mean correlation between series; ${ }^{5}$ Autocorrel.$=$ serial correlation coefficient for the chronology at a lag of $1 \mathrm{yr}$ (i.e. the first order autocorrelation); ${ }^{6}$ Correl. coeff. with O-J Neuquén River streamflow $=$ correlation coefficient between the October-June Neuquén River streamflow and the composite chronologies (Bold numbers indicate significant values at the $0.05 \alpha$-level).

$\operatorname{AR}(n)$ is the autoregressive process of order $n$ used to model the tree-ring series (Cook, 1987) The autocorrelation order $n$ was determined by the minimum Akaike information criterion procedure (Priestley, 1992).

designed to reduce $50 \%$ of the variance in a sine wave with a periodicity of $150 \mathrm{yr}$ (Cook and Peters, 1981). The individual series from each site were combined into ARSTAN chronologies (i.e. composed of series with autoregressive persistence added back after standardization; see Cook, 1985 for details) and their variance was adjusted to account for changes in sample size backward in time (Osborn et al., 1997). Principal component analysis was used to identify common patterns of variations in tree growth across the region. The period used in the principal component analysis was 1800-1950 AD, which coincides with the interval of higher replication of site chronologies. This assures that the signal in each record is representative of the stand growth, reducing the noise associated with low series replication in early periods of the chronologies. After identifying common patterns of variations in the records from each species, the ring width series from individual chronologies, contributing to a PC with a factor loading $>0.60$, were combined to develop regional composite chronologies (Fig. 1 in the Supplement shows the factor loadings of each chronology). Regional chronologies were developed using negative exponential curves or straight lines of any slope to standardize the ring width series.

The quality of the chronologies was assessed on the basis of the following statistics: mean sensitivity (MS), the average correlation between all series (RBAR), the expressed population signal (EPS) and the first-order autocorrelation of the series. Mean sensitivity represents a measure of the interannual variability in tree-rings (Fritts, 1976), whereas the RBAR is a measure of the common variance between all series in a chronology (Wigley et al., 1984). Running RBAR illustrates changes in the strength of common patterns of tree growth over time. EPS measures how well the finitesample chronology compares with a theoretical population chronology based on an infinite number of trees (Wigley et al., 1984). The RBAR and EPS values were computed using a 50-yr moving window with a 25 -yr overlap. We used the EPS cutoff point of 0.85 , suggested by Wigley et al. (1984), to identify the period with reasonable signal strength in each chronology (Table 1, Fig. 2 in the Supplement).

\subsection{Reconstruction method}

To identify the relationships between streamflow and tree growth, we computed correlation coefficients between treering width indices from the composite chronologies and monthly mean Neuquén River streamflow records (Fritts, 1976; Blasing et al., 1984). The highest correlation was generally found between tree-ring composite chronologies and the mean seasonal flows from October to June (9-month period). This mean 9-month streamflow series shows no significant departure from normality (Shapiro-Wilk $W=0.987$; $p=0.421)$.

A nested principal component regression (PCR) approach, which accounts for the decrease in the number of predictor chronologies backward in time, was chosen to reconstruct 
mean October-June Neuquén River streamflow (Meko, 1997; Cook et al., 1999, 2002). All composite ARSTAN chronologies were initially lagged $(t=0, t-1, t+1$, and $t+2)$ to capture possible climate-related persistence in the tree-ring series (Fritts, 1976). The overlap period between the instrumental streamflow record and the tree-ring chronologies (1903-2000) was split into two periods, using the interval 1951-2000 for calibration and reserving the interval 19031950 for verification of the model. Then, we reversed the process and tested the model selecting the earliest years (1903-1950) for calibration and withholding the latest years (1951-2000) for verification. A principal component analysis (PCA) was calculated on the pool of series significantly correlated $(p<0.05)$ with mean October-June streamflow during the calibration period. Following the Kaiser-Guttman rule, the eigenvectors with eigenvalues $>1$ were retained for the multiple regression, further reducing the dimensionality of the dataset. The final subset of principal component in the regression model was determined using the minimum AIC criterion, which includes a penalty term for increasing the number of predictors in the model (Akaike, 1974). The model skill was evaluated using the reduction of error (RE), the coefficient of efficiency (CE), and the sign test statistics, three tests of fitness commonly used in dendrochronology (Fritts, 1976; Cook et al., 1999). We applied this technique to develop six reconstruction models based on different sets of increasingly longer tree-ring composite series, in which the shortest series were excluded one at a time. The models were finally calibrated over the complete 1903-2000 overlapping period and used to reconstruct the predictand series over the full length of the composite tree-ring series. To derive the final reconstruction, we spliced together the reconstructed series of the models that showed the best calibration and verification statistics. The mean and variance of each reconstructed series were adjusted (normalized) to that of the most replicated nest in order to minimize artifact-related changes in variance through time (see D'Arrigo et al., 2011).

The relative influence of each predictor (composite chronology) on the final reconstruction during the common nest period was evaluated by considering the absolute value of the standardized regression coefficients or beta weights (Cook et al., 1999, 2002). The beta weights represent the principal component loadings of the predictor chronologies in the model and are calculated by multiplying the matrix of retained eigenvectors by the vector of beta weights in the principal component space (Cook et al., 1994). We summed up the absolute beta weights for composite chronologies where the $t, t-1, t+1$ and $t+2$ series were included as predictors, and then divided by the total sum of the beta weights for all predictors in the complete calibration model to calculate a measure of relative variance explained $(0 \%-100 \%)$ for each composite (Frank and Esper, 2005).

Intensity and duration of events (droughts or pluvials) in the Neuquén River streamflow were examined by computing the five lowest and highest reconstructed $n$ year running means for $n=1,5,11$, and $25 \mathrm{yr}$. The most severe $n$ year events from the instrumental period were calculated for comparison with the reconstructed record of streamflow. A drought was simply defined as a year or a set of consecutive years below the long-term mean. The frequency of droughts of $1-12 \mathrm{yr}$ in length was calculated together with the mean drought interval (MDI, the number of years between two consecutive droughts of the same length). We also analyzed the distribution of extreme dry years $(<10$ th percentile) over the reconstruction period.

The frequency domains of the instrumental and reconstructed streamflow variations in the Neuquén River were assessed using power-spectral and coherency analyses (Jenkins and Watts, 1968). The Blackman-Tukey (BT) spectra were computed over the period 1903-2000, common to both the actual and reconstructed records. Twenty lags (20\% of the series length) of the auto- and cross-covariance functions were employed and smoothed with the Hamming filter. The $95 \%$ confidence level of the spectrum was estimated from a "red noise", first-order Markov null continuum based on the lag-1 autocorrelation of the time series (Mitchell et al., 1966). We also used BT and singular spectral analyses (SSA) to establish the significant dominant periods in which variance occurs in the streamflow reconstruction. The BT spectrum in this series was estimated using 131 lags of the autocorrelation function ( $20 \%$ of the series length). This provides a reasonable balance between high resolution and moderate stability. SSA is basically a statistical technique related to empirical orthogonal function analysis to determine oscillatory modes in the time space. Similar to other spectral techniques, the choice of lags in SSA is a compromise between the amount of information to be retained (resolution) and statistical significance (stability). We experimented with lags ranging from 1 to $5 \%$ of the series length and found that a lag equal to $2 \%$ of the series length $(11 \mathrm{yr})$ adequately resolved most decadal-scale oscillatory modes.

In order to identify the influence of El Niño-Southern Oscillation (ENSO) and the Southern Annular Mode (SAM, also known as Antarctic Oscillation - AAO) on the Neuquén streamflow, Pearson's correlation coefficients were calculated between the streamflow reconstruction and (a) sea surface temperature from the El Niño 3.4 region (ERSST.v3B Niño 3.4), (b) the Southern Oscillation Index (SOI), and (c) an extended SAM index (Visbeck, 2009). Niño 3.4. and SAM series are available at http://www.cpc.ncep.noaa.gov/ data/indices/, whereas the SAM record was obtained from http://www.ifm-geomar.de/index.php?id=sam. Correlations were assessed after prewhitening all records to avoid the spurious influence of the series' autocorrelation on the statistical significance of results. Correlations using 21-yr central moving windows were also calculated to assess possible temporal changes in the strength of the relationships between the reconstruction and these large-scale indices. 
Table 2. Calibration and verification statistics for six nested reconstruction models. The models used in the final nested reconstruction are shown in bold.

\begin{tabular}{|c|c|c|c|c|c|c|c|c|c|c|c|c|}
\hline \multirow{2}{*}{$\begin{array}{l}\text { Model (period } \\
\text { covered by } \\
\text { predictors) }\end{array}$} & \multicolumn{4}{|c|}{ Number of variables } & \multirow{2}{*}{$\begin{array}{c}\text { Verification } \\
\text { period }\end{array}$} & \multirow[t]{2}{*}{$r_{\mathrm{adj}}^{2 e}$} & \multirow{2}{*}{$\begin{array}{l}\text { Variance } \\
\text { explained } \\
\quad(\%)\end{array}$} & \multirow[t]{2}{*}{$P^{\mathrm{f}}$} & \multirow[t]{2}{*}{$\mathrm{RE}^{\mathrm{h}}$} & \multirow[t]{2}{*}{$\mathrm{CE}^{\mathrm{h}}$} & \multirow{2}{*}{$\begin{array}{l}\text { Sign } \\
\text { test }^{\mathrm{g}}\end{array}$} & \\
\hline & $N_{\mathrm{lc}}^{\mathrm{a}}$ & $N_{\mathrm{sc}}^{\mathrm{b}}$ & $N_{\mathrm{pp}}^{\mathrm{c}}$ & $N_{\mathrm{fp}}^{\mathrm{d}}$ & & & & & & & & \\
\hline \multirow[t]{3}{*}{ 1. 1711-2000 } & 28 & 11 & 5 & 2 & 1903-2000 & & 0.449 & 47.2 & & & & \\
\hline & & & & & $1951-2000$ & $1903-1950$ & 0.472 & 49.4 & 0.702 & 0.283 & 0.234 & $40+10-$ \\
\hline & & & & & 1903-1950 & $1951-2000$ & 0.438 & 45.0 & 0.671 & 0.422 & 0.353 & $37+11-$ \\
\hline \multirow[t]{3}{*}{ 2. 1676-2000 } & 24 & 10 & 4 & 2 & 1903-2000 & & 0.459 & 48.2 & & & & \\
\hline & & & & & 1951-2000 & 1903-1950 & 0.528 & 55.7 & 0.746 & 0.394 & 0.352 & $42+8-$ \\
\hline & & & & & 1903-1950 & 1951-2000 & 0.438 & 45.0 & 0.671 & 0.422 & 0.353 & $37+11-$ \\
\hline \multirow[t]{3}{*}{ 3. 1646-2000 } & 20 & 9 & 3 & 3 & 1903-2000 & & 0.423 & 43.5 & & & & \\
\hline & & & & & $1951-2000$ & 1903-1950 & 0.521 & 55.1 & 0.742 & 0.402 & 0.361 & $42+8-$ \\
\hline & & & & & 1903-1950 & $1951-2000$ & 0.438 & 45.0 & 0.671 & 0.422 & 0.353 & $37+11-$ \\
\hline \multirow[t]{3}{*}{ 4. $1487-2000$} & 16 & 8 & 3 & 3 & 1903-2000 & & 0.441 & 45.3 & & & & \\
\hline & & & & & $1951-2000$ & 1903-1950 & 0.493 & 51.4 & 0.717 & 0.412 & 0.371 & 41+9- \\
\hline & & & & & 1903-1950 & 1951-2000 & 0.438 & 45.0 & 0.671 & 0.422 & 0.353 & $37+11-$ \\
\hline \multirow[t]{3}{*}{ 5. 1346-2000 } & 12 & 5 & 2 & 2 & 1903-2000 & & 0.419 & 43.1 & & & & \\
\hline & & & & & 1951-2000 & 1903-1950 & 0.468 & 49.0 & 0.700 & 0.393 & 0.351 & $39+11-$ \\
\hline & & & & & 1903-1950 & 1951-2000 & 0.368 & 38.2 & 0.618 & 0.383 & 0.309 & $36+12-$ \\
\hline \multirow[t]{3}{*}{ 6. 1161-2000 } & 8 & 4 & 2 & 2 & 1903-2000 & & 0.307 & 32.2 & & & & \\
\hline & & & & & 1951-2000 & $1903-1950$ & 0.406 & 43.0 & 0.656 & 0.22 & 0.160 & $35+13-$ \\
\hline & & & & & 1903-1950 & $1951-2000$ & 0.289 & 30.4 & 0.551 & 0.066 & -0.046 & $35+13-$ \\
\hline
\end{tabular}

${ }^{\mathrm{a}} N_{\mathrm{lc}}=$ number of lagged composite chronologies, ${ }^{\mathrm{b}} N_{\mathrm{sc}}=$ number lagged composite chronologies significantly correlated with the streamflow record, ${ }^{\mathrm{c}} N_{\mathrm{pp}}=$ number of PCs in pool of potential predictors, ${ }^{\mathrm{d}} N_{\mathrm{fp}}$ and number of PCs included as predictors in final model, ${ }^{\mathrm{e}} r_{\text {adj }}^{2}$, the square of the multiple correlation coefficient adjusted for loss of degrees of freedom, ${ }^{\mathrm{f}} P=$ Pearson's correlation coefficient, ${ }^{\mathrm{g}}$ Sign Test results for calibration period indicate number of years in which tree-ring estimates correctly, + (incorrectly, - ) track sign of observations (Cook et al., 1990). Verification: ${ }^{\mathrm{h}} \mathrm{RE}=$ reduction of error, ${ }^{\mathrm{h}} \mathrm{CE}=$ coefficient of efficiency statistics.

\section{Results}

\subsection{The tree-ring network}

The PCA grouped the Araucaria chronologies into six significant components, which accounted for 40.1, 8.3, 6.4, 6.2, 4.8 and $4.3 \%$ of the total variance of the records. The Austrocedrus chronologies were also grouped into six significant components accounting for 37.0, 11.8, 7.7, 5.9, 4.3 and 3.6\% of the total variance (see Table 1 in the Supplement). Based on the factor loadings, the chronologies of both species were combined into six composite chronologies (Araucaria: AR1, AR2, AR3, AR4, AR5 and AR6; Austrocedrus: AU1, AU2, AU3, AU4, AU5 and AU6). However, as the total number of tree-ring series in the AR4, AR5 and AR6 composite chronologies was lower than 50 series, these composites were not included in the analyses. The number of treering radii in the remaining composite chronologies ranges between 64 and 541 (Table 1).

\subsection{Analysis of the reconstruction}

Table 2 shows the calibration and verification statistics for the different regression models used to reconstruct the Neuquén River streamflow. Model 2 shows a slightly higher statistical skill than Model 1 and was therefore selected to estimate streamflow for the more recent period, 16762000 AD. Models 4 and 5 also show reasonable skill in predicting streamflow and were used to extend back in time the reconstruction (back to 1487 and 1346 AD with Models 4 and 5, respectively). The skill of the regression model extending further back in time the reconstructed series (Model 6, Table 2) is poor compared to the better replicated models. Thus, Model 6 was not included in the reconstruction. The final nested reconstruction, based on the Araucaria and Austrocedrus composite tree-ring chronologies, spans from 1346 to $2000 \mathrm{AD}$ (Fig. 3). The three intervening models explain between 43.1 and $48.2 \%$ of the total variance in the instrumental streamflow record over the common period 1903-2000 (Table 2). The $F$ value of these models ranges between 21.59 and 39.27 , and their calibration and verification (RE and $\mathrm{CE}$ ) statistics remain positive for the segments 1903-1950 and 1951-2000 (Table 2). The sign test results, an indication of how well the tree-ring estimates track the direction of change in climate from year to year, were significant at or above the 0.05 level for these models. Analyses of regression residuals indicate no violations of regression assumptions. The residuals of the regression models are approximately normally distributed and not significantly autocorrelated, according to Durbin-Watson tests (Fig. 3b). Model 6, based on a reduced number of predictors (AU4 and 

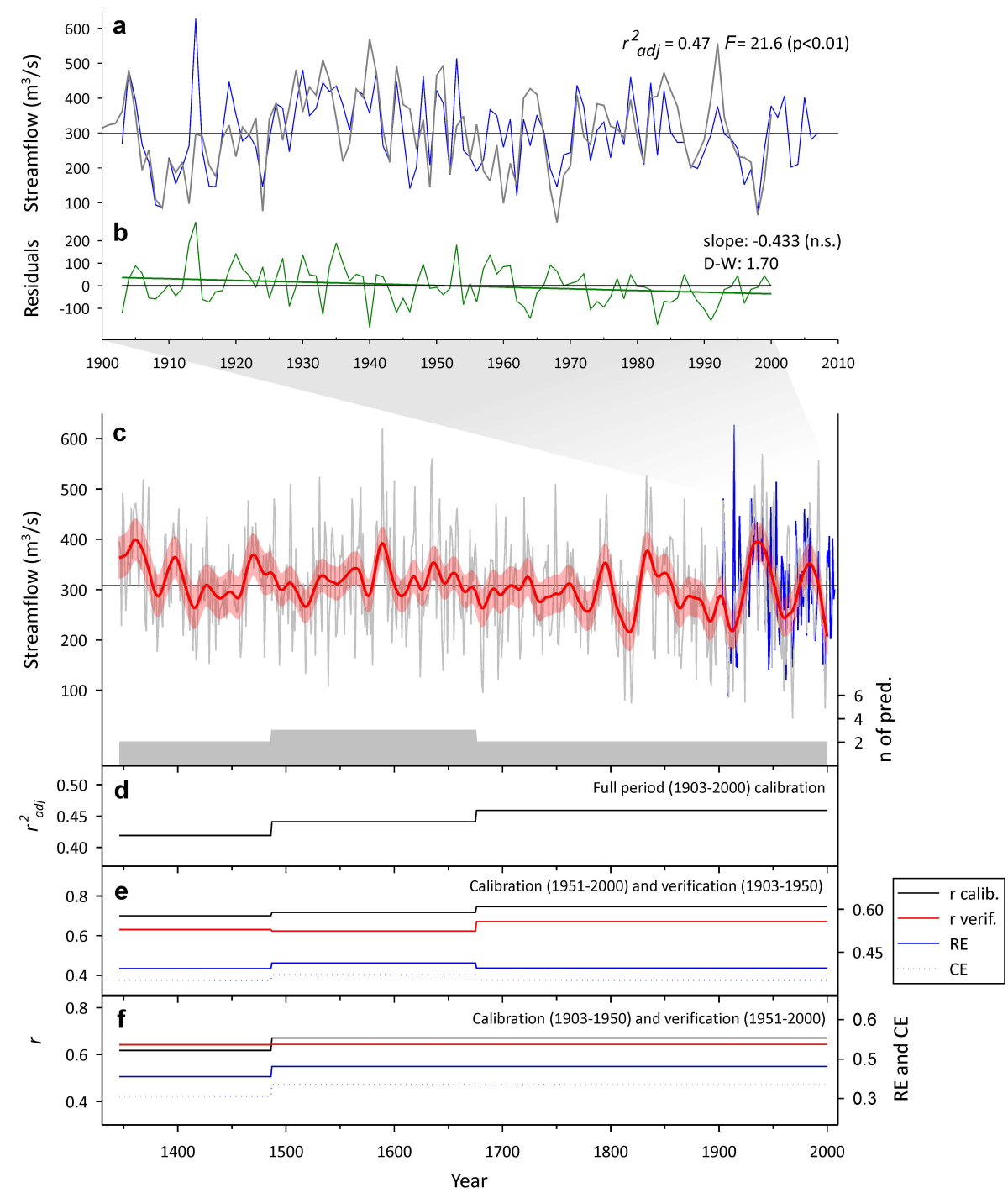

Fig. 3. October-June Neuquén River streamflow reconstruction for the past 655 yr. (a) Instrumental (blue) and nested tree-ring reconstructed (gray) streamflow for the 1903-2000 common period. The coefficient of determination (an indicator of the proportion of variance explained by regression) adjusted for the degrees of freedom in the model $\left(r_{\mathrm{adj}}^{2}\right)$, the $F$-value of regression (the ratio between the explained and the unexplained variability in the model) for Model 2 are also shown. Regression residuals for the reconstruction are shown in (b). The linear trend of regression residuals (slope) and the Durbin-Watson (D-W) statistics used to test for first-order autocorrelation of the regression residuals are also indicated. (c) Nested tree-ring based reconstruction of the October-June Neuquén River streamflow for the period 1346-2000. The thick red line represents a 25-yr cubic spline to emphasize the long-term variations in the Neuquén River streamflow reconstruction. Red shading represents the $\pm 2 \mathrm{SE}$ uncertainty bands in this smoothed series. Gray shading reflects the number of predictors available over time. (d) Variations in the adjusted coefficient of determination $\left(r_{\mathrm{adj}}^{2}\right)$ for the full period calibration. (e) and (f) Pearson correlation coefficient $(r)$, the reduction of error (RE), the coefficient of efficiency $(\mathrm{CE})$ for the split calibration and verification periods.

AU6), shows a lower percentage of variance accounted for by regression and RE and CE values close to zero (Table 2).

The beta weights for Model 2 are shown in Fig. 1b. Seven composite chronologies were retained for modeling, and weights were distributed across the region and species type. The mean relative variance explained for all composite chronologies was $16.7 \%$, ranging from $0.1 \%$ to $27.4 \%$. The highest values were observed for Austrocedrus composite chronologies (AU1, AU4 and AU6), which grouped tree-ring chronologies from southern and northern sites of the basin.

\subsection{Frequency, intensity and duration of extreme events}

The Neuquén River reconstructed record (1346-2000) shows important inter-annual to multi-decadal variability, with transitions from dry to wet or wet to dry intervals being common 
Table 3. Lowest and highest $n$ year moving averages of the reconstructed (1346-2000) and measured streamflow (1903-2009). Events are non-overlapping averages of the mean October-June Neuquén River streamflow $\left(\mathrm{m}^{3} \mathrm{~s}^{-1}\right)$ for $n$ year periods. Ranks $1-5$ are the most severe reconstructed events and actual is the most severe observed event.

\begin{tabular}{lcccc}
\hline \multirow{2}{*}{ Rank } & \multicolumn{4}{c}{ Droughts } \\
\cline { 2 - 5 } & $1 \mathrm{yr}$ & $5 \mathrm{yr}$ & $10 \mathrm{yr}$ & $25 \mathrm{yr}$ \\
\hline 1 & $43.7(1968)$ & $161.3(1817-1821)$ & $188.8(1908-1917)$ & $236.2(1802-1826)$ \\
2 & $64.1(1998)$ & $161.7(1909-1913)$ & $193.3(1812-1821)$ & $237.5(1889-1913)$ \\
3 & $74.2(1819)$ & $167.9(1889-1893)$ & $194.9(1888-1897)$ & $264.8(1952-1976)$ \\
4 & $75.7(1924)$ & $171.6(1966-1970)$ & $226.5(1858-1867)$ & $270.4(1765-1789)$ \\
5 & $79.2(1813)$ & $177.7(1958-1962)$ & $229.6(1953-1962)$ & $271.0(1677-1701)$ \\
Actual & $78.1(1998)$ & $186.7(1995-1999)$ & $242.9(1990-1999)$ & $277.9(1975-1999)$ \\
\hline \multirow{2}{*}{ Rank } & & 5 & Pluvials & \\
& $15 \mathrm{yr}$ & $5 \mathrm{yr}$ & $10 \mathrm{yr}$ & $25 \mathrm{yr}$ \\
\cline { 2 - 5 } 1 & $619.9(1589)$ & $456.2(1589-1593)$ & $421.4(1829-1838)$ & $385.5(1349-1373)$ \\
2 & $570.3(1940)$ & $446.1(1833-1837)$ & $419.9(1584-1593)$ & $378.4(1927-1951)$ \\
3 & $560.8(1635)$ & $442.7(1357-1361)$ & $414.5(1359-1368)$ & $356.6(1465-1489)$ \\
4 & $556.7(1992)$ & $438.2(1929-1933)$ & $407.0(1932-1941)$ & $356.0(1828-1852)$ \\
5 & $540.9(1634)$ & $435.5(1938-1942)$ & $397.3(1634-1643)$ & $355.1(1582-1606)$ \\
Actual & $627.3(1914)$ & $413.0(1930-1934)$ & $402.2(1930-1939)$ & $350.3(1925-1949)$ \\
\hline
\end{tabular}

throughout the reconstruction (Fig. 3c). Overall, the reconstructed record shows drought events more severe than those recorded in the instrumental record. In contrast, reconstructed pluvial events are generally less extreme (i.e. not as wet) as those observed during the calibration period. A list of the lowest and highest streamflows reconstructed for the Neuquén River since 1346 shows that three of the five lowest October-June streamflows occurred during the 20th century, with the lowest being 1968 (Table 3). In both, measurements and reconstruction, one of the driest years of the instrumental period is 1998, representing also the second driest year of the entire 1346-2000 reconstruction. In relation to the highest streamflow years, the years 1940 and 1992 were reported in this category during the 20th century. Across the streamflow reconstruction the 5-yr lowest streamflow periods were 1817-1821 and 1909-1913, and the two 5-yr highest streamflow periods were 1589-1593 and 1833-1837. Three of the 5 -yr lowest and two of the 5-yr highest streamflow periods were recorded in the 20 th century.

In terms of the 10-yr moving averages, the period from 1908 to 1917 was ranked the driest among the five lowest streamflow events over the past $655 \mathrm{yr}$, and the period from 1829 to 1838 was ranked at the top of the highest streamflows in the last six centuries. Longer periods with low streamflow values in the reconstruction were 1802-1826, 1889-1913, 1952-1976, 1765-1789, and 1677-1701 (Fig. 3c).

The analysis of the frequency of single- to multiple-year droughts shows an expected decline from a large number of single year droughts to fewer, increasingly longer droughts (Fig. 4). The longest dry period was centered in the 18881897 period. In terms of frequency, the mean drought

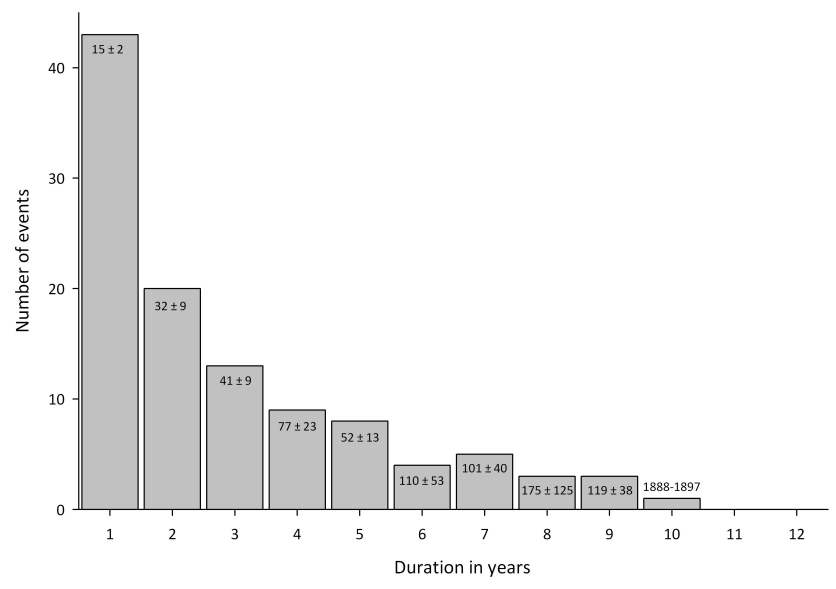

Fig. 4. Histogram showing the frequency of $n$-year drought events (one to 12 consecutive years below the long-term mean) for the 1346-2000 AD Neuquén River streamflow reconstruction. The long-term mean (1346-2000) was used for comparisons, because the values are normally distributed (Shapiro Wilk test $W=0.999$, $p=0.861$ ). Numbers inside the bars indicate the mean drought interval plus or minus one standard error (SE).

interval (MDI) ranges between $15 \mathrm{yr}$ for single events to $175 \mathrm{yr}$ for 8-yr droughts.

The extreme dry years (<10th percentile) are not evenly distributed throughout the complete reconstruction period and were slightly more frequent during the 19th and 20th centuries than in the previous four centuries (Fig. 5). Of particular note is the clustering of extreme dry years during the 1810-1820s, 1860s, 1910s and at the end of 1960s, with 


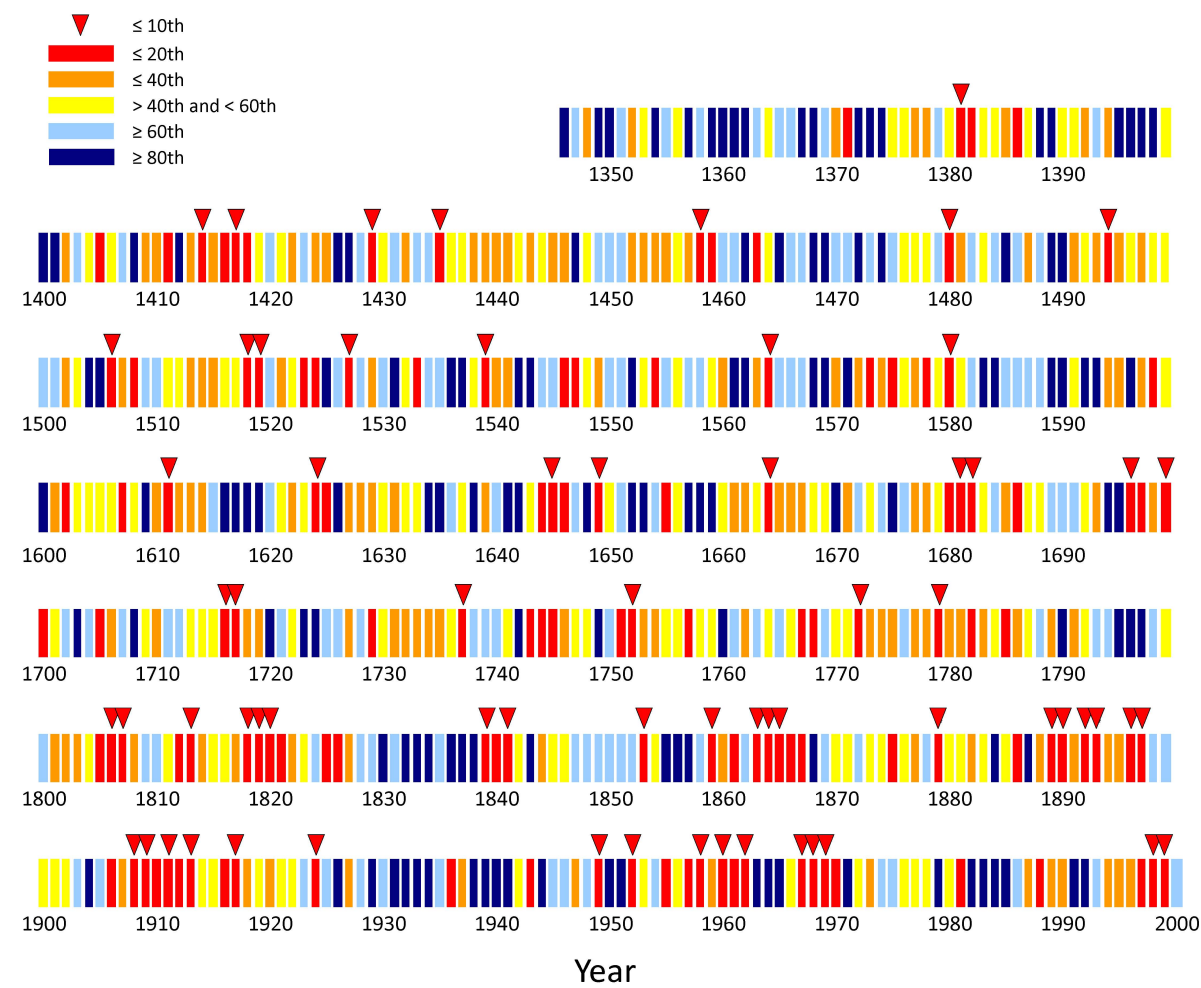

Fig. 5. Reconstructed Neuquén River streamflow values categorized by percentile. Values are shading-coded according to percentiles of flow. The years with triangles are the driest $10 \%$ of flows.

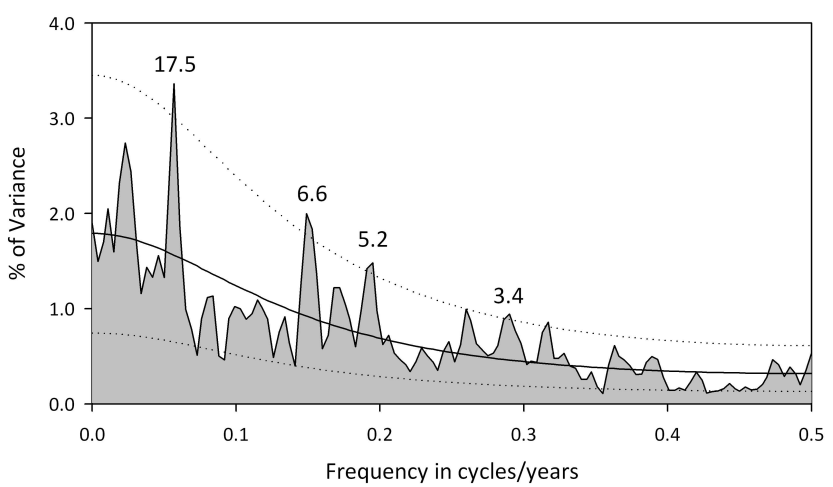

Fig. 6. Blackman-Tukey spectral density of the reconstructed Neuquén River streamflow (1346-2000). The dotted lines represent the $95 \%$ confidence interval and the dashed line is the red noise band.

three consecutive years of extreme drought in 1818-1820, 1863-1865 and 1967-1969. Dry extremes are less frequent and more evenly distributed over the 15th, 16th, 17th and 18 th centuries.

\subsection{Spectral analyses}

Results from a coherence spectral analysis between the observed and reconstructed streamflows over the common period 1903-2000 revealed congruence at interannual, decadal, and interdecadal time scales, with significant squared coherency at around 2.5-3.3, 10, 13, 20 and 40-yr cycles.

The Blackman-Tukey spectrum of the reconstructed Neuquén River streamflow over the period 1346-2000 shows peaks that exceed the $95 \%$ confidence limit at 17.5, 6.6, 5.2 and $3.4 \mathrm{yr}$ (Fig. 6). Six major waveforms, representing decadal to interannual modes of common variance at 47 , $17.6,6.8,5.1$ and $3.8 \mathrm{yr}$, were isolated from the streamflow reconstruction using singular spectral analysis (Vautard and Ghil, 1989; Fig. 8). The temporal evolution of these components accounts for $84.4 \%$ of the total variance in the reconstruction.

\subsection{Large-scale climatic influences}

Variations in the Neuquén River streamflow reconstruction are not significantly related to ENSO variations tested using SSTs in the Niño 3.4 zone $(r=0.128, p=0.374)$ or the SOI index $(r=-0.251, p=0.079)$. In contrast, variations in the Neuquén streamflow reconstruction and the annual SAM index are significantly negatively correlated $(r=-0.384, p<0.01)$ over the $1887-2000$ period (Fig. 8a). However, correlations using a 21 -yr central moving window revealed an interesting pattern with changes in the strength of these correlations over time. The reconstructed Neuquén 


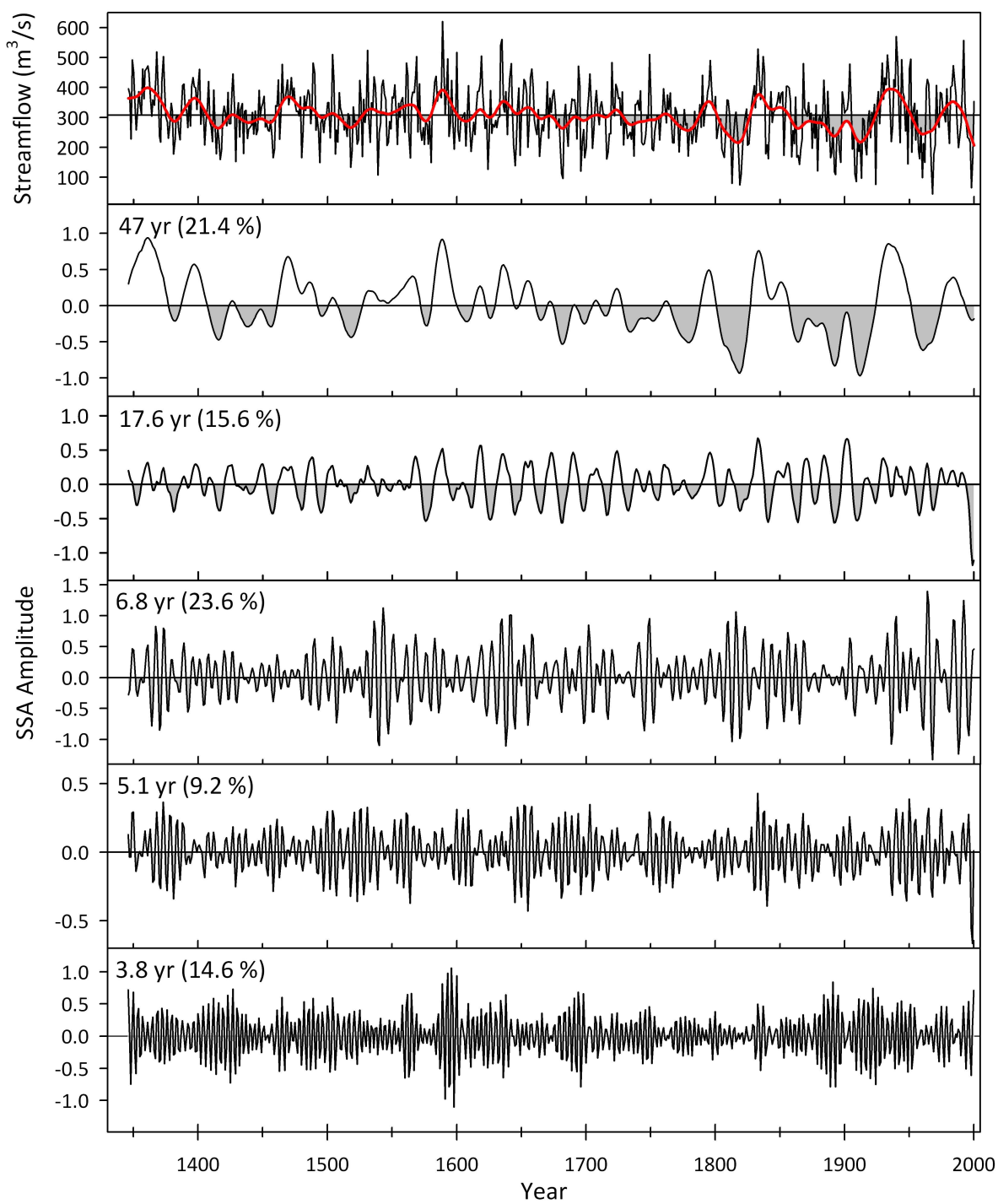

Fig. 7. The Neuquén River streamflow reconstruction (top panel) and its most significant oscillation modes estimated using singular spectrum analysis (SSA). Units are dimensionless. Periods in years and the percentage of variance associated with each waveform are shown in the upper-left corners of the streamflow waveforms.

River streamflow was significantly correlated with SAM at the end of 19th century - beginning of 20th century (18971920) and at mid (1943-1958) and end of the 20th century (Fig. 8b).

Spatial correlations between the instrumental and reconstructed October-June Neuquén River streamflow and the geopotential heights $(500 \mathrm{hPa})$ were determined for the area $20^{\circ} \mathrm{N}-85^{\circ} \mathrm{S} / 180^{\circ} \mathrm{E}-0^{\circ}$ (Fig. 9). In terms of zonal patterns, both streamflow series show similar correlation results with the $500 \mathrm{hPa}$ geopotential heights. Consistent with the SAM relationship previously described, October-Juner Neuquén River streamflow is positive and significantly correlated with $500 \mathrm{hPa}$ geopotential heights over key circum-Antarctic regions during the October-June period (Fig. 9).

\section{Discussion}

In this paper we presented a tree-ring based reconstruction of mean October-June Neuquén River streamflow, which complemented and extended the pioneering reconstruction by Holmes et al. (1979) for the 1601-1968 period. This new series extends back in time the Neuquén River streamflow by $290 \mathrm{yr}$, substantially increases the number of tree-ring chronologies used as predictors, and applies newer methods for capturing the mean and variance of the instrumental record over a significantly longer calibration period. To our knowledge, the Neuquén River reconstruction represents the longest streamflow reconstruction in South America.

The Araucaria araucana and Austrocedrus chilensis composite chronologies used in this study are robust, 


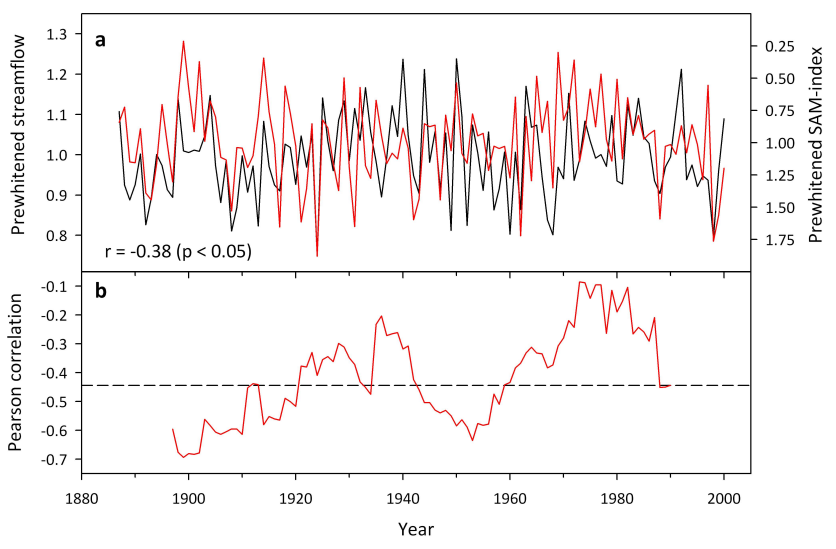

Fig. 8. (a) Relationship between the October-June Neuquén River streamflow (black) and annual SAM index (red) for the period 1887-2000. SAM index has been inverted to facilitate the comparison with the streamflow data. (b) 21-yr central moving correlations between the streamflow and the annual SAM index. Dashed lines indicate the $95 \%$ significance level. Note the change in strength of this relationship over time.

well-replicated proxy climate records. The descriptive statistics of the composite chronologies are comparable to those previously reported for both species (Villalba et al., 1998; Mundo et al., 2011). During the 1676-2000 period, the greatest contribution to the streamflow $(41.0 \%)$, expressed as percentage of beta weigths, was provided by the AU6 composite, which grouped two chronologies (Melado and Huinganco) at the northern limit of the basin $\left(35^{\circ} 52^{\prime} \mathrm{S}-\right.$ $\left.37^{\circ} 07^{\prime} \mathrm{S}\right)$. A $50.1 \%$ contribution to the streamflow reconstruction was additively provided by AU1 and AU4 composite series, which grouped chronologies located to the south $\left(39^{\circ} 15^{\prime} \mathrm{S}-41^{\circ} 10^{\prime} \mathrm{S}\right)$ and north $\left(32^{\circ} 39^{\prime} \mathrm{S}-34^{\circ} 46^{\prime} \mathrm{S}\right)$ of the Neuquén River basin, respectively. The significant correlation between these chronologies and the Neuquén River streamflow suggests that the precipitation regime in the Neuquén watershed represents a transitional pattern between the central Chile and the northern Patagonia precipitation regimes. This situation was also recorded for the Maule watershed located at $35^{\circ} \mathrm{S}-36^{\circ} 30^{\prime} \mathrm{S}$ on the Chilean slope of the Andes (Urrutia et al., 2011).

The models used to develop the final nested reconstruction explain 43.1 to $48.2 \%$ of the total variance in the OctoberJune Neuquén River streamflow over the 1903-2000 calibration period. This range of values is similar to those reported for the streamflow reconstructions of the binational Puelo River (Lara et al., 2008) and the Chilean Maule River (Urrutia et al., 2011) on the western side of the north Patagonian Andes. The total variance explained by our model is lower than that recorded in the previous reconstruction of the annual Neuquén River streamflow developed by Holmes et al. $(1979 ; 53.3 \%)$. We believe that the use by Holmes et al. (1979) of highly correlated chronologies as predictors of the Neuquén River streamflow in a multiple regression model
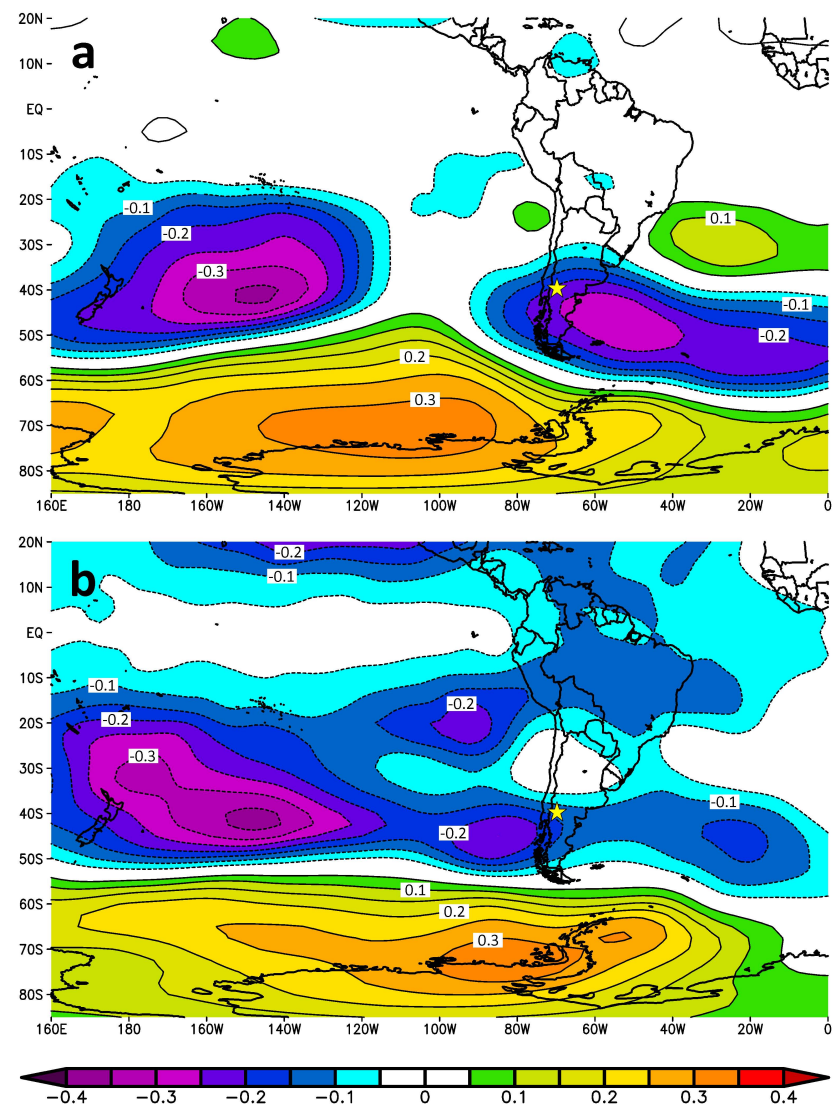

NCEP/NCAR Reanalysis

Correlation

NOAA/ESRL Physical Sciences Division

Fig. 9. Spatial correlation patterns during the interval 1948-2000 between October-June $500 \mathrm{HPa}$ geopotential height anomalies and (a) instrumental and (b) reconstructed October-June Neuquén River streamflow. The yellow stars indicate the location of Paso de Indios gauging station. Solid and dashed contours indicate positive and negative correlations, respectively; zero contours are omitted. Correlation analyses and gridded geopotential height data were obtained from the National Oceanic and Atmopheric Administration website (http://www.esrl.noaa.gov/psd/data/correlation/).

may have partially inflated the percentage of variance accounted for by the regression equation in this earlier study.

The 20th century has seen some of the driest and wettest annual to decadal events in the past six centuries, but longer and more severe events were reconstructed in previous centuries. Four of the five years with the lowest streamflows in the last $655 \mathrm{yr}$ occurred in the 20th century. The lowest reconstructed streamflow was in 1968 (the sixth lowest gauge record), which was also a very severe drought year north of the Neuquén basin, affecting water availability for irrigation, water consumption in the city of Mendoza and electric power generation in the Atuel River (Prieto et al., 2010). Although 1968 is not considered a La Niña event, it presented a distinctive pattern of cold anomalies in the tropical Pacific, characteristic of the cold episodes of ENSO (Rutland and Fuenzalida, 1991).The lowest observed streamflow 
was in 1998, which was also the second lowest year in the reconstruction. In 1998-1999, strong La Niña conditions in the western tropical Pacific and an anomalously high polarity of the Antarctic Oscillation (i.e. a strengthened polar vortex; Thompson and Wallace, 2000) led to severe drought in northern Patagonia (annual rainfall was the lowest since recordings began in 1905). This climatic event resulted in massive mortality of the evergreen tree Nothofagus dombeyi near its eastern distributional limit towards the Patagonian steppe (Suarez et al., 2004). Additionally, during the 1998-1999 fire season, more than 14,000 ha burned in the Nahuel Huapi National Park alone (Veblen et al., 2003). The year 1998 was also reported among the 10 driest years in the December PDSI reconstruction for the Temperate-Mediterranean transition (TMT) zone of the Andes in Chile $\left(35.5^{\circ}-39.5^{\circ} \mathrm{S}\right.$; Christie et al., 2010). The forth lowest reconstructed streamflow was in 1924, which was also the year with the lowest annual precipitation recorded in Santiago de Chile (Rutllant and Fuenzalida, 1991), the lowest reconstructed annual streamflow of Maule watershed (Urrutia et al., 2011), and a wellknown La Niña event (Diaz and Markgraf, 2000). Three of the four driest years in the 20th century in the Neuquén River streamflow reconstruction (1908, 1924, 1968, and 1998) were also registered as part of the 10 driest years of the 800 year central Chile precipitation reconstruction (Le Quesne et al., 2006). Two of the 5-yr periods with the lowest streamflows closely match with periods observed in the Puelo River and Maule River streamflow reconstructions (1908-1917 and 1812-1821). The period 1817-1821 also had a close correspondence with the low annual precipitation registered in a tree-ring based reconstruction for northern Patagonia (Villalba et al., 1998).

Pluvial events in the 20th century rank among the wettest in the reconstruction, but in some cases the intensity of these events was underestimated by the model (see e.g. the year 1914), suggesting that the reconstruction was conservative in the representation of extreme wet events. This limitation is a common feature in hydroclimatic reconstructions from treerings and it has been identified by several authors (Maxwell et al., 2011; Masiokas et al., 2012). The year 1940, ranked second in high flows in our reconstruction, was also reported as one with the highest flows in the streamflow reconstruction for the Puelo (Lara et al., 2008) and Maule Rivers (Urrutia et al., 2011) in northern Patagonia. This year was also recorded as one of the highest pluvials in a precipitation reconstruction based on Nothofagus pumilio tree-ring chronologies in the Central Andes of Chile (Lara et al., 2001).

Blackman-Tukey and singular spectral analyses applied to the reconstruction indicate that the spectral variability in this record is dominated by a 6.6-6.8-yr cycle, which explains approximately $23.6 \%$ of the total variance (Figs. 6 and 7). Similar oscillations were also found in the Puelo River streamflow reconstruction (5-6.5 yr; Lara et al., 2008) and in the annual precipitation reconstruction for northern Patagonia (6.2-6.4 yr; Villalba et al., 1998). Power spectra and singular spectral analysis of the streamflow reconstruction also indicate the presence of lower-frequency oscillations at periods of approximately $17.6 \mathrm{yr}$. Oscillations of $17 \mathrm{yr}$ have also been documented in temperature and precipitation reconstructions for northern Patagonia (Villalba et al., 1996, 1998). In the Neuquén river streamflow reconstruction, this periodicity is more evident from 1600 to around 1890 (Fig. 7). This fact was already detected in the Puelo River reconstruction (Lara et al., 2008) and it is also a common pattern in several proxy records across the Pacific basin, suggesting that interdecadal variations in this region were probably more conspicuous prior to the 20th century (see e.g. Villalba et al., 2001).

As discussed above, information on past droughts and pluvial events, their recurrence and periodicity, may be of great importance for the water resource management in the Neuquén River basin. Our analyses show that the instrumental record of Neuquén River streamflow does not adequately represent the full range of variability that can be observed over the past 655 years. Although several extreme droughts and pluvial events have occurred during the period of the instrumental record, we were able to detect in our reconstruction a number of more severe drought events prior to the 20th century (e.g. 1413-1418, 1644-1646, 1680-1682, 1743-1745, 1805-1807, 1818-1821, 1839-1841, 18631867, 1889-1897; Fig. 5).

Previous studies have reported significant relationships between ENSO and mean annual discharges of the Neuquén River (Scarpati et al., 2001; Seoane et al., 2005). However, the comparison between pre-whitened variations of both ENSO and October-June Neuquén River flow (both observed and reconstructed records) reveals positive, but not statistically significant correlations between these variables. This might be related to a weaker influence of ENSO over the Andean portion of the Neuquén basin (Garreaud et al., 2009), and the transitional location of the study area between the ENSO-dominated climate of Central Chile to the north and the SAM-dominated climate across Patagonia to the south.

Recent studies of Araucaria araucana fire regimes in northern Patagonia show that large fires are associated with positive SAM departures, concurrent with La Niña events in the tropical Pacific (Mundo, 2011). Dry springs were also related to the combination of positive anomalies in SAM and La Niña conditions in the Pacific Ocean. Fogt and Bromwich (2006) and Fogt et al. (2011) have shown that the magnitude of ENSO teleconnections over South America intensifies when positive SAM anomalies occur in phase with La Niña events. Although there was a slight tendency of low and high streamflows during La Niña and El Niño events along the 20th century, we were not able to determine, with the exception of a few years (1924 and 1998), clear interactions between SAM and ENSO on the Neuquén River discharge. We noted that streamflow variations in the study area are more consistently related to variations in the SAM. The positive phase of SAM is associated with a decrease in surface pressure and geopotential heights over Antarctica and a 
strengthening and poleward shift of the Westerlies (Garreaud et al., 2009). These conditions tend to produce a marked decrease in rainfall in northern and central Patagonia, whereas during the negative phase of SAM, an increase in precipitation can be observed in the region (Aravena and Luckman, 2009).

Changes in the relationships between the reconstructed Neuquén River streamflow and the SAM over time, as recorded in Fig. 8, might be associated with the persistent trend in the SAM toward its positive phase since late 1950s. Observational analyses of sea-level pressure on the Southern Hemisphere have shown a statistically significant increase in the difference in zonal mean sea level pressure (MSLP) between $40^{\circ} \mathrm{S}$ (increasing) and $65^{\circ} \mathrm{S}$ (decreasing), with the trend being most pronounced since the mid-1960s (Marshall, 2003). Changes in the 1960s reflect the marked shift southward of the subtropical band in the Southern Hemisphere (see e.g. van Loon et al., 1993; Hurrell and van Loon, 1994). These changes in atmospheric circulation may have introduced changes in the strength of the relationship between SAM and the Neuquén River streamflow.

The streamflow reconstruction described in this paper might be used as input for water system models to assess the reliability of water supply systems under a broader range of conditions than afforded by the gauge record alone. Collaborative work with water managers to make streamflow reconstructions compatible with current planning and management tools should be encouraged. Several issues that might be investigated are (1) the fidelity of the tree-ring data in reflecting the severe drought conditions in particular years (e.g. 1998), (2) the uncertainty in the reconstructions and their incorporation into water management strategies and modeling, and (3) the feasibility of reconstructing other hydroclimatic metrics that are also critical to water managers in the region.

This study is especially useful in understanding the temporal variability of water availability in northern Patagonia, where water is fundamental for economic activities such as hydroelectric power generation, agriculture and tourism. According to the IPCC in its Fourth Assessment Report, the Andean region in northwestern Patagonia is projected to experience an important reduction in precipitation by the end of the 21st century (Christensen et al., 2007). Detailed, quantitative information on past hydrological changes may provide base information to better prepare for these drier scenarios. Further improvements in the existing reconstructions could be achieved by expanding the temporal and spatial coverage of the tree-ring network in northern Patagonia. Similar reconstruction exercises could be performed for other neighboring Patagonian rivers of great socio-economic importance, such as the Colorado, Limay and Chubut. The integration of streamflow reconstructions into water management practices and infrastructure planning appears as a challenging goal, which will require significant efforts and close collaboration between hydrologists, dendroclimatologists, climatologists, and regional water resource managers.

\section{Supplementary material related to this article is available online at: http://www.clim-past.net/8/815/2012/ cp-8-815-2012-supplement.pdf.}

Acknowledgements. This research was supported by the InterAmerican Institute for Global Change Research (IAI-CRN 2047), FONDECYT (Grants no. 1090479 and 1121106) and by a CONICET (National Council for Scientific and Technical Research of Argentina) post-doctoral fellowship. We thank the Subsecretaría de Recursos Hídricos de la Nación (National Agency of Water Resources of Argentina) for providing the record of Paso de Indio gauge in Neuquén province. We also thank Petr Stepanek for providing the AnClim software which allowed the calculation of power spectra (http://www.climahom.eu). We also thank Duncan Christie, the communicating editor, and the two reviewers (Connie Woodhouse and Gregory Pederson) for improving the final version of this contribution.

Edited by: D. Christie

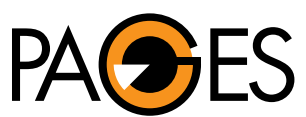

The publication of this article was sponsored by PAGES.

\section{References}

Akaike, H.: A new look at the statistical model identification, IEEE T. Automatic Control AC, 19, 716-723, 1974.

Almeyda, A. E. and Sáez, S. F.: Recopilación de Datos Climáticos de Chile y Mapas Sinópticos Respectivos, Ministerio de Agricultura, Santiago de Chile, 1958.

Aravena, J. C. and Luckman, B. H.: Spatio-temporal rainfall patterns in southern South America, Int. J. Climatol., 29, 21062120, 2009.

Blasing, T. J., Solomon, A. M., and Duvick, D. N.: Response function revisited, Tree-Ring Bull., 44, 1-15, 1984.

Case, R. A. and MacDonald, G. M.: Tree ring reconstructions of streamflow for three Canadian Prairie rivers, J. Am. Water. Resour. Assoc., 39, 703-716, 2003.

Christensen, J. H., Hewitson, B., Busuioc, A., Chen, A., Gao, X., Held, I., Jones, R., Kolli, R. K., Kwon, W.-T., Laprise, R., Magaña Rueda, V., Mearns, L., Menéndez, C. G., Räisänen, J., Rinke, A., Sarr, A., and Whetton, P.: Regional climate projections, in: Climate Change 2007: the physical science basis. Contribution of working group I to the fourth assessment report of the Intergovernmental Panel on Climate Change, edited by: Solomon, S., Qin, D., Manning, M., Chen, Z., Marquis, M., Averyt, K. B., Tignor, M., and Miller, H. L., Cambridge University Press, Cambridge, 847-940, 2007.

Christie, D. A., Boninsegna, J. A., Cleaveland, M., Lara, A., Le Quesne, C., Morales, M., Mudelsee, M., Stahle, D., and Villalba, R.: Aridity changes in the Temperate-Mediterranean transition of the Andes since AD 1346 reconstructed from tree-rings, Clim. Dynam., 36, 1505-1521, doi:10.1007/s00382-009-0723-4, 2010.

Cook, E. R.: A time series analysis approach to tree ring standardization, University of Arizona, School of Renewable Natural Resources, Tucson, 1985. 
Cook, E. R.: The decomposition of tree-ring series for environmental studies, Tree-Ring Bull., 47, 37-59, 1987.

Cook, E. R. and Jacoby, G. C.: Potomac River streamflow since 1730 as reconstructed by Tree Rings, J. Clim. Appl. Meteorol., 22, 1659-1672, 1983.

Cook, E. R. and Peters, K.: The smoothing spline: a new approach to standardizing forest interior tree-ring width series for dendroclimatic studies, Tree-Ring Bull., 41, 45-53, 1981.

Cook, E. R., Briffa, K., Shiyatov, S., and Mazepa, V.: Treering standardization and growth-trend estimation, in Methods of dendrochronology - applications in the environmental sciences, edited by: Cook, E. and Kairiukstis, L. A., Kluwer Academic Publishers, Amsterdam, 104-132, 1990.

Cook, E. R., Briffa, K., and Jones, P.: Spatial regression methods in dendroclimatology: A review and comparison of two techniques, Int. J. Climatol., 14, 379-402, 1994.

Cook, E. R., Meko, D. M., Stahle, D. W., and Cleaveland, M. K.: Drought reconstructions for the continental United States, J. Climate, 12, 1145-1162, 1999.

Cook, E. R., D'Arrigo, R., and Mann, M.: A well-verified, multiproxy reconstruction of the winter North Atlantic Oscillation index since A.D. 1400, J. Climate, 15, 1754-1764, 2002.

D’Arrigo, R. D., Abram, N., Ummenhofer, C., Palmer, J., and Mudelsee, M.: Reconstructed streamflow for Citarum River, Java, Indonesia: linkages to tropical climate dynamics, Clim. Dynam., 36, 451-462, doi:10.1007/s00382-009-0717-2, 2011.

Diaz, H. F. and Markgraf, V.: El Niño and the Southern Oscillation: multiscale variability, global and regional impacts, Cambridge University Press, Cambridge, 2000.

Donoso-Zegers, C.: Bosques templados de Chile y Argentina, Editorial Universitaria, Santiago de Chile, 1993.

Fogt, R. L. and Bromwich, D. H.: Decadal variability of the ENSO teleconnection to the high-latitude south Pacific governed by coupling with the Southern Annular Mode*, J. Climate, 19, 979997, doi:10.1175/JCLI3671.1, 2006.

Fogt, R. L., Bromwich, D. H., and Hines, K. M.: Understanding the SAM influence on the South Pacific ENSO teleconnection, Clim. Dynam., 36, 1555-1576, doi:10.1007/s00382-010-0905-0, 2011.

Frank, D. and Esper, J.: Temperature reconstructions and comparisons with instrumental data from a tree-ring network for the European Alps, Int. J. Climatol., 25, 1437-1454, 2005.

Fritts, H. C.: Tree Rings and Climate, Academic Press, London, 1976.

Garreaud, R. D., Vuille, M., Compagnucci, R., and Marengo, J.: Present-day South American climate, Palaeogeogr. Palaeocl., 281, 180-195, doi:10.1016/j.palaeo.2007.10.032, 2009.

Holmes, R. L., Stockton, C. W., and LaMarche, V. C.: Extension of river flow records in Argentina from long tree-ring chronologies, J. Am. Water. Resour. Assoc., 15, 1081-1085, 1979.

Hurrell, J. W. and van Loon, H.: A modulation of the atmospheric annual cycle in the Southern Hemisphere, Tellus A, 46, 325-338, doi:10.1034/j.1600-0870.1994.t01-1-00007.x, 1994.

Jenkins, G. M. and Watts, D. G.: Spectral analysis and its applications, Holden-Day, San Francisco, 1968.

LaMarche, V. C., Holmes, R. L., Donwiddie, P., and Drew, L.: Treering chronologies of the southern hemisphere: 1 . Argentina, University of Arizona, Tucson, 1979.
Lara, A., Aravena, J. C., Villalba, R., Wolodarsky-Franke, A., Luckman, B. H., and Wilson, R.: Dendroclimatology of highelevation Nothofagus pumilio forests at their northern distribution limit in the central Andes of Chile, Can. J. Forest. Res., 31, 925-936, 2001.

Lara, A., Villalba, R., and Urrutia, R. B.: A 400-year tree-ring record of the Puelo River summer-fall streamflow in the Valdivian Rainforest eco-region, Chile, Climatic Change, 86, 331356, doi:10.1007/s10584-007-9287-7, 2008.

Le Quesne, C., Stahle, D. W., Cleaveland, M. K., Therrell, M. D., Aravena, J. C., and Barichivich, J.: Ancient Austrocedrus treering chronologies used to reconstruct central Chile precipitation variability from a.d. 1200 to 2000, J. Climate, 19, 5731-5744, doi:10.1175/JCLI3935.1, 2006.

Le Quesne, C., Acuña, C., Boninsegna, J. A., Rivera, A., and Barichivich, J.: Long-term glacier variations in the Central Andes of Argentina and Chile, inferred from historical records and tree-ring reconstructed precipitation, Palaeogeogr. Palaeocl., 281, 334-344, doi:10.1016/j.palaeo.2008.01.039, 2009.

Marshall, G. J.: Trends in the Southern Annular Mode from observations and reanalyses, J. Climate, 16, 4134-4143, doi:10.1175/1520-0442(2003)016<4134:TITSAM > 2.0.CO;2, 2003.

Masiokas, M. H., Villalba, R., Christie, D. A., Betman, E., Luckman, B. H., Le Quesne, C., Prieto, M. R., and Mauget, S.: Snowpack variations since AD 1150 in the Andes of Chile and Argentina $\left(30^{\circ}-37^{\circ} \mathrm{S}\right)$ inferred from rainfall, tree-ring and documentary records, J. Geophys. Res., 117, D05112, doi:10.1029/2011JD016748, 2012.

Maxwell, R. S., Hessl, A. E., Cook, E. R. and Pederson, N.: A multispecies tree ring reconstruction of Potomac River streamflow (950-2001), Water Resour. Res., 47, W05512, doi:10.1029/2010WR010019, 2011.

Meko, D.: Dendroclimatic reconstruction with time varying predictor subsets of tree indices, J. Climate, 10, 687-696, doi:10.1175/1520-0442(1997)010<0687:DRWTVP>2.0.CO;2, 1997.

Mitchell, J. M., Dzerdseevskii, B., Flohn, H., Hofmeyr, W. L., Lamb, H. H., Rao, K. N., and Wallen, C. C.: Climatic change, World Meteorological Organization, Geneva, 1966.

Morales, M. S. and Boninsegna, J. A.: ENSO signal in a new long tree-line chronology from Austrocedrus chilensis at Huinganco, Neuquén, Argentina, in International Conference of Dendrochronology for the Third Millenium, Laboratorio de Dendrocronología, IANIGLA-CONICET, Mendoza, Argentina, p. 235, 2000.

Mundo, I. A.: Historia de incendios en bosques de Araucaria araucana (Molina) K. Koch de Argentina a través de un análisis dendroecológico, Tesis Doctoral, Universidad Nacional de La Plata, La Plata, Argentina, 2011.

Mundo, I. A., Roig Juñent, F. A., Villalba, R., Kitzberger, T. and Barrera, M. D.: Araucaria araucana tree-ring chronologies in Argentina: spatial growth variations and climate influences, TreesStruct. Funct., 26, 443-458, doi:10.1007/s00468-011-0605-3, 2012.

Osborn, T. J., Briffa, K., and Jones, P. D.: Adjusting variance for sample-size in tree-ring chronologies and other regional mean time series, Dendrochronologia, 15, 89-99, 1997. 
Priestley, M. B.: Spectral analysis and time series, Academic Press, London, 1992.

Prieto, M. R., Araneo, D., and Villalba, R.: The Great Droughts of 1924-25 and 1968-69 in the Argentinean Central Andes: Socioeconomic impacts and responses, in II International Symposium "Reconstructing Climate Variations in South America and the Antarctic Peninsula over the last 2000 years", CIN-Facultad de Ciencias Forestales y Recursos Naturales, UACH-PAGES, Valdivia, Chile, p. 57, 2010.

Rutllant, J. and Fuenzalida, H.: Synoptic aspects of the central Chile rainfall variability associated with the Southern Oscillation, Int. J. Climatol., 11, 63-76, 1991.

Scarpati, O. E., Spescha, L., Fioriti, M. J., and Capriolo, A. D.: El Niño driven climate variability and drainage anomalies in Patagonian region, Argentina, Cuadernos de Investigación Geográfica, 27, 179-191, 2001.

Seoane, R. S., Valdés, J. B., and Mata, L. J.: Climate variability and climate change in Patagonian rivers, in IAHS-AISH Publication 295, Foz do Iguaçu, 26-34, 2005.

Stockton, C. W.: Long-Term Streamflow Records Reconstructed From Tree-Rings, University of Arizona, Tucson, Arizona, 1975.

Suarez, M. L., Ghermandi, L., and Kitzberger, T.: Factors predisposing episodic drought-induced tree mortality in Nothofagus site, climatic sensitivity and growth trends, J. Ecol., 92, 954-966, 2004.

Thompson, D. W. J. and Wallace, J. M.: Annular modes in the extratropical circulation, Part I: Month-to-month variability, J. Climate, 13, 1000-1016, 2000.

Urrutia, R. B., Lara, A., Villalba, R., Christie, D. A., Le Quesne, C. and Cuq, A.: Multicentury tree ring reconstruction of annual streamflow for the Maule River watershed in south central Chile, Water Resour. Res., 47, W06527, doi:10.1029/2010WR009562, 2011.

van Loon, H., Kidson, J. W., and Mullan, A. B.: Decadal variation of the annual cycle in the Australian dataset, J. Climate, 6, 12271231, 1993.

Vautard, R. and Ghil, M.: Singular spectrum analysis in nonlinear dynamics, with applications to paleoclimatic time series, Physica D, 35, 395-424, doi:10.1016/0167-2789(89)90077-8, 1989.
Veblen, T. T.: Regeneration patterns in Araucaria araucana forests in Chile, J. Biogeogr., 9, 11-28, 1982.

Veblen, T. T., Kitzberger, T., Raffaele, E., and Lorenz, D. C.: Fire History and Vegetation Changes in Northern Patagonia, Argentina, in: Fire and Climatic Changes in Temperate Ecosystems of the Western Americas, vol. 160, edited by: Veblen, T. T., Baker, W. L., Montenegro, G., and Swetnam, T. W., SpringerVerlag, New York, 265-295, 2003.

Villalba, R. and Veblen, T. T.: Spatial and temporal variation in Austrocedrus growth along the forest-steppe ecotone in northern Patagonia, Can. J. Forest. Res., 27, 580-597, 1997.

Villalba, R., Boninsegna, J. A., Lara, A., Veblen, T. T., Roig, F. A., Aravena, J. C., and Ripalta, A.: Interdecadal climatic variations in millennial temperature reconstructions from southern South America, in: Climatic variations and forcing mechanisms of the last 2,000 years, vol. 41, edited by: Jones, P. D., Bradley, R. S., and Jouzel, J., Springer, Berlin, 161-189, 1996.

Villalba, R., Cook, E. R., Jacoby, G. C., D’Arrigo, R., Veblen, T. T., and Jones, P. D.: Tree-ring based reconstruction of northern Patagonia precipitation since AD 1600, Holocene, 8, 659-674, 1998.

Villalba, R., D’Arrigo, R. D., Cook, E. R., Jacoby, G. C., and Wiles, G.: Decadal-scale climatic variability along the extratropical western coast of the Americas: evidence from tree-ring records, in: Interhemispheric climate linkages, edited by: Markgraf, V., Academic Press, San Diego, 155-170, 2001.

Visbeck, M.: A station-based Southern Annular Mode index from 1884 to 2005, J. Climate, 22, 940-950, 2009.

Wigley, T. M. L., Briffa, K., and Jones, P. D.: On the average value of correlated time series, with applications in dendroclimatology and hydrometeorology, J. Clim. Appl. Meteorol., 23, 201-213, 1984.

Woodhouse, C. A. and Lukas, J.: Multi-century tree-ring reconstructions of Colorado streamflow for water resource planning, Climatic Change, 78, 293-315, 2006.

Woodhouse, C. A., Gray, S. T., and Meko, D. M.: Updated streamflow reconstructions for the Upper Colorado River Basin, Water Resour. Res., 42, W05415, doi:10.1029/2005WR004455, 2006. 